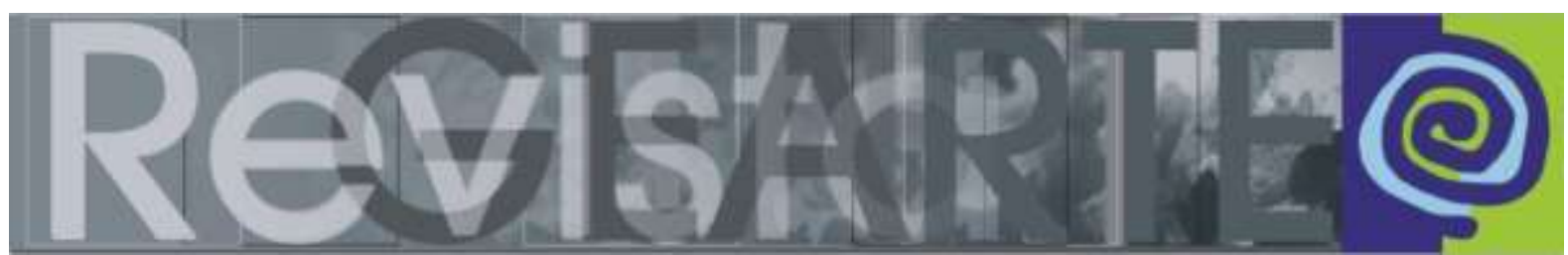

ISSN 2357-9854

\title{
O conhecimento secreto de David Hockney e as múltiplas janelas de tempo nos desenhos de Jandira Lorenz
}

\author{
Sandra Makowiecky (UDESC - Brasil) \\ Vanessa Bortucan de Oliveira (Artista visual - Brasil)
}

\begin{abstract}
RESUMO
Pensando na relação "leitura visual: arte, mídia e cotidiano", entre ciência e imagem e nos processos de produção de imagens com problemas estéticos e de representação, alguns artistas nos chamam a atenção, pois utilizam a própria arte como fonte de aprendizagem, em procedimento científico, de forma mais explícita. Um deles é David Hockney, que com o livro "O Conhecimento Secreto", nos explica como tenta redescobrir as técnicas perdidas dos grandes mestres, mostrando seu fascínio pela pintura, pelo mágico universo surgido da capacidade e necessidade que tem o homem de representar a realidade e de inventá-la. O outro é a artista plástica Jandira Lorenz, professora de história da arte, que em sua produção revela sobrevivências, sintomas de sua experiência com os estudos em arte. Este artigo visa construir um pensamento em relação à montagem de tempos históricos diversos nas obras da artista Jandira Lorenz com o livro de David Hockney que contribuiu com a possibilidade de estabelecer um ponto de convergência quanto às características de multiplicidades e particularidades na compreensão das imagens vistas por janelas múltiplas na recente pesquisa do acervo completo de desenhos de Jandira Lorenz. Ao enfocar a ligação desses dois artistas com a arte e a ciência, sobretudo, enfatizamos o valor da pesquisa artística.
\end{abstract}

PALAVRAS-CHAVES

David Hockney. Jandira Lorenz. Múltiplas janelas. Montagem. Arte e ciência.

\section{ABSTRACT}

Thinking about the relationship "visual lecture: art, media and quotidian", science and image and the process of producing images with aesthetic and representation problems, some artists draw our attention because they use their own art as a source of learning, in a scientific procedure, more explicitly. One of them is David Hockney, who with the book "The Secret Knowledge", explains how to try to rediscover the lost techniques of the great masters, showing his fascination for painting, for the magical universe emerged of the capacity and need the man has to represent reality and invent it. The other is the artist Jandira Lorenz, also a professor of art history, who with her production reveals survival, symptoms of her experience with studies in art. This paper aims to build a thought regarding the assembly of various historical periods in works of the artist Jandira Lorenz with the book by David Hockney, who contributed to the possibility of establishing a point of convergence on the characteristics of multiplicities and particularities in understanding the images seen by multiple windows in the recent research of the complete collection of drawings by Jandira Lorenz. By focusing on the connection between these two artists with art and science, we emphasize the value of artistic research.

\section{KEYWORDS}

David Hockney. Jandira Lorenz. Multiple windows. Assembly. Art and science.

Para o tema da relação "leitura visual: arte, mídia e cotidiano", entre ciência e imagem e nos processos de produção de imagens com problemas estéticos e de representação, pensamos em escrever sobre uma possível faceta da relação entre

MAKOWIECKY, Sandra; OLIVEIRA, Vanessa Bortucan de. O conhecimento secreto de David 37

Hockney e as múltiplas janelas de tempo nos desenhos de Jandira Lorenz.

Revista GEARTE, Porto Alegre, v. 2, n. 1, p. 37-60, abril. 2015.

Disponível em: http://seer.ufrgs.br/gearte 
ciência e imagem, escolhendo mais notadamente o eixo que privilegia processos de produção de imagens e problemas estéticos e de representação. Pensamos que este texto aborda aspectos da problemática teórico-metodológica do estatuto da imagem como fonte sócio-histórica e sua relação com outros tipos de fontes, sobretudo quando considera a própria arte como fonte de aprendizagem, em procedimento científico.

Um dos objetos de nossa atenção é o livro "O Conhecimento Secreto", de David Hockney (2001), em que o "artista tenta redescobrir as técnicas perdidas dos grandes mestres, mostrando seu fascínio pela pintura, pelo mágico universo surgido da capacidade e necessidade que tem o homem de representar a realidade e de inventála", nos diz Ferreira Gullar (2002), em resenha denominada "A Técnica Perdida". Vale registrar outros aspectos destacados na resenha de Gullar. O que David Hockney pretendia mostrar ao penetrar neste universo, seria uma possível comprovação de que muitos artistas não se valeram apenas da vista desarmada para apreender e representar a realidade. Valeram-se de instrumentos ópticos desde o século XV. Para comprovar sua tese, Hockney tenta, trilhando passos bem didáticos, ampliar sua visão do problema e ao final afirma que se no passado, "os artistas sabiam usar uma ferramenta, esse conhecimento se perdeu", discutindo suas teses com estudiosos da arte e da óptica, avaliando suas observações e hipóteses, ao mesmo tempo em que retomava a vinculação do passado entre arte e ciência.

Hockney acredita ter demonstrado que, no passado, alguns artistas usaram instrumentos ópticos e outros não, embora, diz ele, quase todos pareçam ter sido influenciados pelas tonalidades, sombreados e cores encontrados na projeção óptica. Dividido em três partes, o livro de David Hockney, segundo Ferreira Gullar, abre "caminho para uma possível releitura da linguagem pictórica figurativa no vasto período anterior ao Impressionismo e ao surgimento da fotografia propriamente dita. Trata-se, portanto, de um instrumento para a análise filológica da pintura". Acrescenta Gullar que "a maior parte dos analistas de sua pesquisa diz que este trabalho não vai além disso, uma vez que o valor artístico da pintura figurativa não está na maior fidelidade à visão fotográfica do real". Mas é exatamente como instrumento de estudo que ele nos interessa, pois estabelece uma relação entre arte e ciência. 
O outro objeto de nossa atenção é a obra Sem título, 2012, da artista plástica Jandira Lorenz ${ }^{1}$, com a qual este artigo visa construir um pensamento em relação à montagem de tempos históricos diversos na obra da artista. Para tal, a leitura do livro O Conhecimento Secreto contribuiu com a possibilidade de estabelecer um ponto de convergência entre características levantadas na pesquisa de imagens feita pelo artista britânico David Hockney sobre a técnica dos grandes mestres quanto às características de multiplicidades e particularidades na compreensão das imagens vistas por janelas múltiplas e a recente pesquisa do acervo completo de desenhos de Jandira Lorenz.

O termo "janelas múltiplas" se define como várias janelas dentro de uma janela, porém David Hockney enfatiza esse olhar perante pinturas de grandes mestres, enquanto que Georges Didi-Huberman - o autor referência para a construção das analogias, semelhanças e correspondências à poética de Jandira Lorenz - emprega o termo para descrever a condição do fazer histórico (DIDI-HUBERMAN, 2011, p. 56), que descortina a possibilidade de hipóteses e considerações sobre o passado como movimento nos desenhos da artista, devido ao transbordamento de seus desenhos em referências históricas, artísticas e mitológicas.

O objeto da análise, portanto, serão os desenhos de Jandira, abordados por constituírem-se de montagens de tempos anacrônicos, como janelas múltiplas de tempo, visando "abarcar o visual e o temporal reunidos na imagem dialética" (DIDIHUBERMAN, 2011, p. 21), definida por Walter Benjamim, como dialética em suspensão: "a imagem é aquilo em que o ocorrido encontra o agora num lampejo" e

\footnotetext{
1 Jandira Lorenz nasceu no Rio Grande do Sul (05/03/1947). É radicada em Florianópolis, SC, Brasil.

${ }^{2} \mathrm{O}$ índice histórico das imagens diz, pois, não apenas que elas pertencem a uma determinada época, mas, sobretudo, que elas só se tornam legíveis numa determinada época. E atingir essa legibilidade constitui um determinado ponto crítico específico do movimento em seu interior. Todo o presente é determinado por aquelas imagens que lhe são sincrônicas: cada agora é o agora de uma determinada cognoscibilidade. Nele, a verdade está carregada de tempo até o ponto de explodir (...). Não é que o passado lança sua luz sobre o presente ou que o presente lança luz sobre o passado; mas a imagem é aquilo em que o ocorrido encontra o agora num lampejo, formando uma constelação. Em outras palavras: a imagem é a dialética na imobilidade. Pois, enquanto a relação do presente com o passado é puramente temporal, a do ocorrido com o agora é dialética - não de natureza temporal, mas imagética. Somente as imagens dialéticas são autenticamente históricas, isto é, imagens não arcaicas. A imagem lida, quer dizer, a imagem no agora da cognoscibilidade, carrega no mais alto grau a marca do momento crítico, perigoso, subjacente a toda leitura. (BENJAMIN, 2006, p. 505).
} 
forma uma constelação de possibilidades, fazendo que dos detalhes se produzam aparições, permitindo analogias infinitas segundo o olho de quem vê.

A partir do entendimento de janelas múltiplas - pontos de vistas diversificados em relação a uma imagem - muitas imagens irão dialogar com o desenho de Jandira Sem título, 2012 (Figura 6), aqui trazido para análise, pois abre uma discussão que reflete sobre os procedimentos de montagem até então não estudados na história da pintura da forma como fez Hockney ao enfocar o procedimento técnico dos artistas.

A percepção apurada de David Hockney como artista permitiu que ele descobrisse características nas imagens que poucos historiadores da arte se detiveram a considerar. Por isso, o olhar apurado ao passado foi extremamente relevante para sua pesquisa, como também é preponderante para Jandira Lorenz em favor de seu processo criativo.

Ao propor um novo ponto de vista para olhar as imagens de Jandira, principalmente a partir do desdobramento de um olhar singular e investigativo por janelas dentro de uma janela, almeja-se produzir novos ângulos para olhar e entender como as ideias e conceitos caminham junto à realidade plástica para refletir sobre a geologia do sentido. Para Stéphane Huchet (2012, p. 11) "a teoria da arte contemporânea não se concebe como uma atividade de predicação de seu objeto, isto é, de busca de definições ou de confirmação das convenções estéticas e metodológicas", portanto o que este texto visa não é uma definição possível dos desenhos de Jandira Lorenz, mas trazer abordagens a partir de relações, principalmente com o passado histórico e artístico.

Seguindo o mesmo raciocínio de Huchet, Hubert Damisch, em uma entrevista, afirma que "o objeto teórico é um objeto que provoca outros objetos. É um objeto que não pode ser estudado por si próprio. Para nos aproximarmos dele é necessário referir outros objetos" (apud LEAL, 2007, p. 13). É, portanto, ao aproximar o objeto escolhido (desenhos de Jandira) aos outros objetos (no caso, pinturas estudadas por Hockney e posteriormente imagens da história da arte), que a aproximação se constitui, de modo que seja possível abordá-lo por meio da perspectiva comparativa. 
Não há finalidade de usar a teoria como objeto motor de análise e sim o contrário, o objeto é a obra de arte, porém a teoria é aquilo que faz com que a aproximação aos outros objetos se componha. É um meio de criar vínculos entre as coisas e trazer olhares diversos, enriquecendo leituras possíveis. A pretensão não é criar modelos teóricos para compreender o objeto, mas ser ajudado por uma abordagem de modo a construir uma argumentação, como esboço daquilo que se tornou legível a partir de um detalhe e que será escrito para fazer de um lampejo, uma propagação no contemporâneo.

Se uma imagem reúne em si vários tempos heterogêneos, não é possível fazer uma história verdadeira da história das imagens, e por isso, qualquer determinação de significado será uma montagem interpretativa, constituinte de uma memória histórica de um arquivo complexo de um indivíduo. Seja esta imagem aparentemente repleta de outras imagens ou não, sempre será uma montagem, uma coleção de reminiscências, visíveis (materializadas) ou não visíveis (como um arquivo de memórias materializadas em um palimpsesto), pois estas imagens só podem ser vistas quando há um tensionamento entre os indícios que buscamos, de modo a construir tramas quando avistamos os fantasmas que habitam as imagens.

\begin{abstract}
A imagem está, então, abertamente sobredeterminada a respeito do tempo. Isso implica reconhecer o princípio funcional desta sobredeterminação dentro de uma certa dinâmica da memória. Muito antes de que a arte tivesse uma história - que começou ou recomeçou, diz-se, com Vasari -, as imagens foram, levaram e produziram a memória. (DIDI-HUBERMAN, 2011, p. 42).
\end{abstract}

Antes de dar ênfase a uma apresentação anacrônica como possibilidade de olhar os desenhos de Jandira, será brevemente descrito o processo investigativo de Hockney ao redescobrir as técnicas perdidas dos grandes mestres.

No livro O Conhecimento Secreto, David Hockney exemplifica o que ele denomina janelas múltiplas nas pinturas dos mestres do passado, ou seja, várias janelas dentro de uma janela. As montagens analisadas por Hockney apresentam no plano pictórico uma imagem única, como se tudo fosse pintado separado e depois reunido em uma única imagem. Seriam montagens, segundo ele, do tipo colagem. A pintura de Dieric Bouts (Figura 1), apresenta as seguintes características: o candelabro é visto de frente, os rostos também são todos vistos de frente, algumas 
figuras não parecem ter relação umas com as outras, e alguns modelos parecem ter sido usados mais de uma vez. Hockney defende que cada objeto, cada rosto, foi desenhado em separado com uma lente-espelho e o método buraco-na-parede, usando uma janela tal como aquela na parede de fundo e depois reunidos no painel. Por isso, conclui que trata-se de uma colagem, na qual o efeito que se deseja obter é o de trazer tudo para perto do plano pictórico.

Figura 1 - Dieric Bouts, Última Ceia, 1464-1468

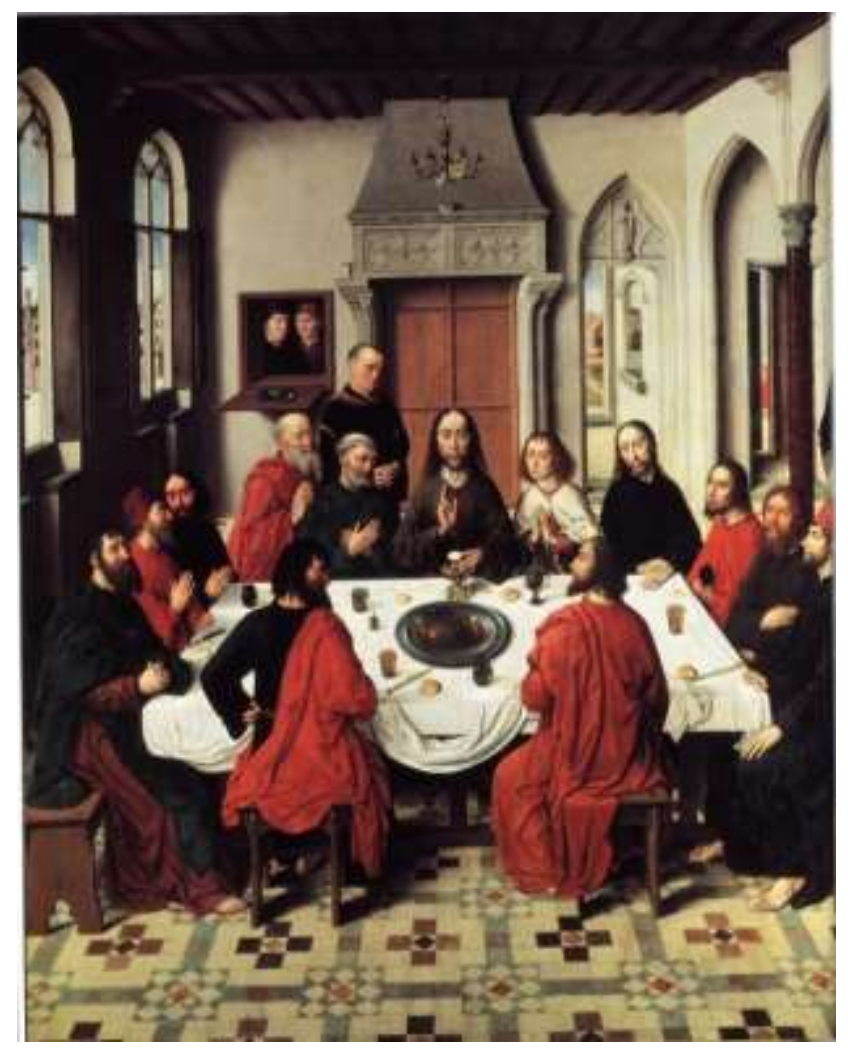

Fonte: HOCKNEY, 2001, p. 86.

Na pintura de Antonello da Messina (Figura 2), pode-se perceber em detalhes como o pintor utilizou-se de recursos para combinar técnicas setentrionais com preocupações italianas. Algumas características incluídas em sua pintura eram incomuns na pintura italiana desse período, como as sombras destacadas, o que segundo David Hockney poderia ser explicada pela iluminação necessária para a lente espelho, que ele poderia ter descoberto com outro mestre da pintura que utilizava-a como ferramenta. Se observarmos atentamente, o recinto é desenhado segundo a perspectiva linear, mas os objetos em seu interior não - são vistos todos de frente, o 
que revela outro tipo de técnica presente na pintura. É como se todos estes objetos tivessem sido desenhados separadamente de modo que fosse possível captar seus detalhes. Várias janelas dentro de uma janela?, pergunta Hockney (2001, p. 99).

Figura 2 - Antonello da Messina, São Jerônimo em seu gabinete, 1460-5, Itália

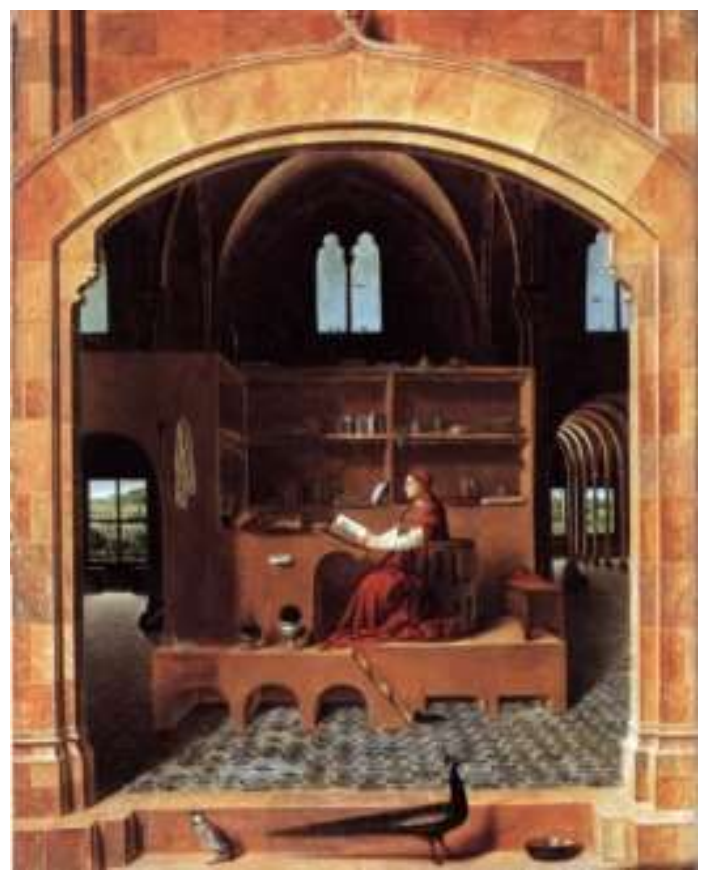

Fonte: HOCKNEY, 2001, p. 98.
Figura 3 - Fragmentos em janelas múltiplas

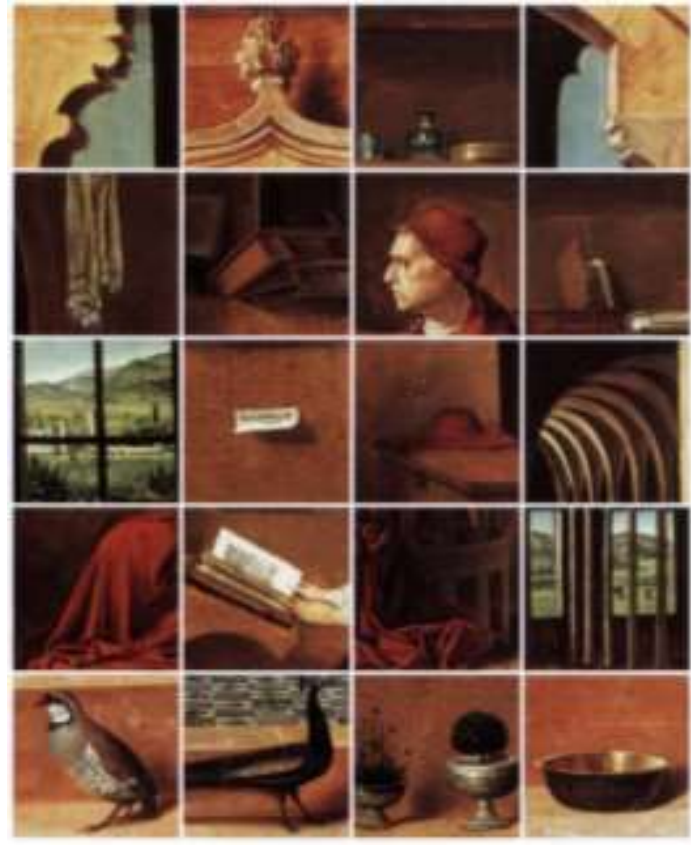

Fonte: HOCKNEY, 2001, p. 99.

A montagem, ao contrário do que parece, não é um artifício recente usado pelos artistas, mas sim algo que sempre esteve presente em toda a história da arte, porém a sistematização teórica sobre o assunto surge somente em tempos mais atuais, principalmente com Aby Warburg e os estudos de Didi-Huberman ao investigar este novo modelo de historicidade warburgiano, que recai sobre o papel das sobrevivências na dinâmica da imaginação do Ocidente, e de como os trabalhos memorialísticos se revelam portadores.

Outro exemplo analisado por David Hockney em seu livro, compara o efeito da montagem na obra $O$ Retábulo de Gante (Figura 5), de Van Eyck e com a fotografia Pearblosson Highway de 1986 (Figura 4), a fim de esclarecer como o artista caracteriza a montagem pela investigação do uso da técnica.

A pintura $O$ Retábulo de Gante apresenta uma estrutura espacial que possibilita uma sensação de grande profundidade. Ao contemplar a obra original, percebe-se 
que sua construção é sofisticada, tudo é visto em close e de frente, mesmo o que está mais longe, aparece em detalhe, extremamente realista. A luz é homogênea, portanto, não proveniente do sol. Pontos de vistas múltiplos criam um espaço bem maior do que pode ser alcançado por um único (respeitando a perspectiva linear). O que sabemos de Van Eyck, é que fazia diversos desenhos de vários elementos e depois desenhava a pintura toda em detalhe a partir deles (HOCKNEY, 2001, p. 94). Em Pearblosson Highway tudo foi reunido a partir de pontos de vista múltiplos e unidos para criar uma sensação de amplitude e profundidade. Ao mesmo tempo tudo foi trazido para o plano pictórico, efeito da técnica de montagem demostrada por David Hockney em sua montagem fotográfica.

Figura 4 - David Hockney, Pearblosson Highway, 1986

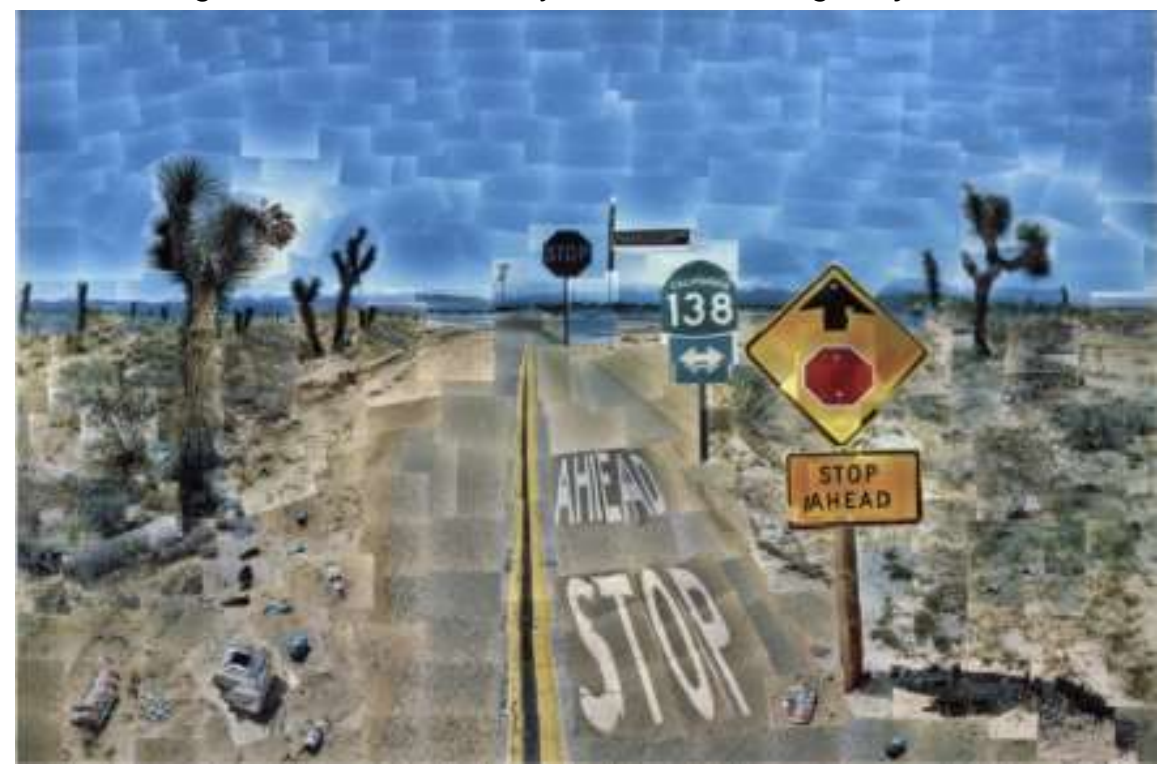

Fonte: HOCKNEY, 2001, p. 95.

Figura 5 - Van Eyck, O Retábulo de Gante, 1432 


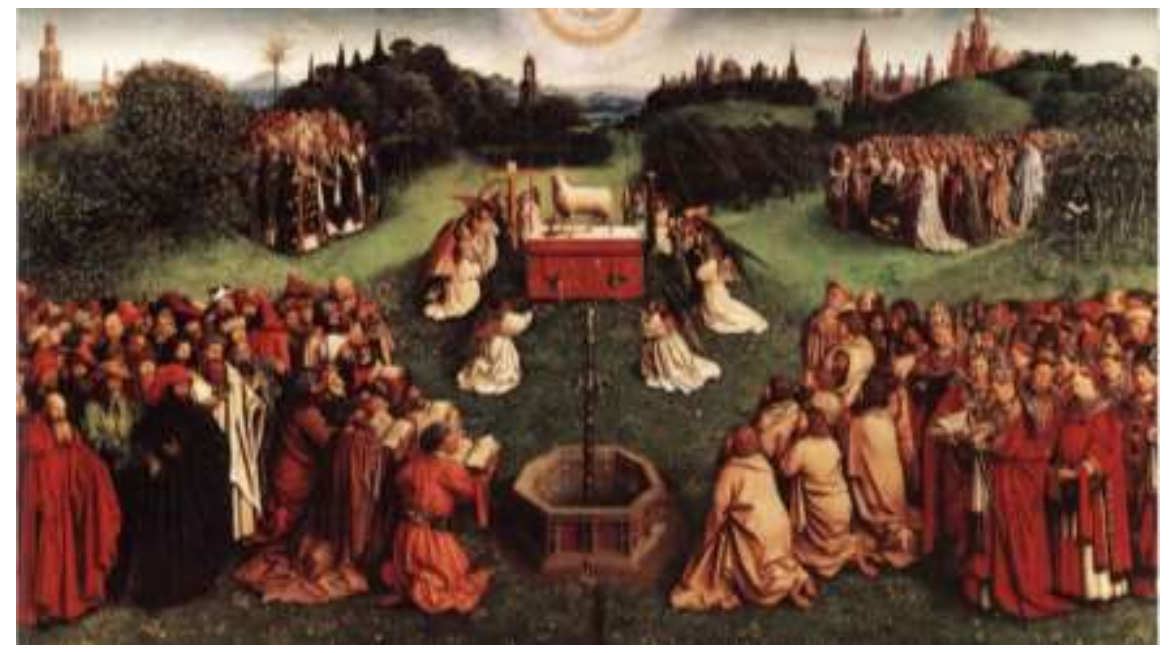

Fonte: HOCKNEY, 2001, p. 95.

Ao refletir sobre as descrições feitas pelo artista sobre as características das duas imagens, verifica-se que a imagem pode nos dar pistas de como ela foi construída, pois se a imagem resguarda potências latentes que saltam quando o olho avista o "Deus que há no detalhe" (DIDI-HUBERMAN, 2013, p. 442-443) é o detalhe que contém a natureza sintomática que produz aparições quando relacionadas.

Hockney defende sua tese, usando a imagem como prova principal e descobre que os artistas do passado, como Caravaggio, Van Eyck, Vélazquez, dentre muitos outros, pintavam a partir de pontos de vista de janelas múltiplas (e com o auxílio de uma ferramenta óptica, fato que neste texto não há intuito de ressaltar por exigir longa explicação técnica). Hockney desenvolve um raciocínio baseado em exemplificações, relações, empirismo e ciência, de como estes artistas construíram imagens de modo a resultar no efeito da técnica de montagem, técnica constante no passado e no presente, como um arquivo que se forma com o tempo, um tempo anacrônico, de construção, reconstrução e depuração, que se apresenta na composição artística, porque se constitui de reelaborações entre o que existiu e o que existe, entre passado e presente, porque as imagens sobrevivem imersas num constante devir em relação ao tempo, como as imagens dos desenhos de Jandira.

As imagens trazem com elas inúmeras possibilidades, para que o observador relacione aquilo que vê à bagagem histórica e cultural da humanidade, experimentando "a metamorfose constante e o deslocamento azimutal das imagens. 
São como borboletas, nos rodeiam com sua dança incessante, com seus movimentos brownianos, com seu contagiante pulular" (DIDI-HUBERMAN, 2007, p. 63) ${ }^{3}$.

Hockney apresenta colagens de tempo presente, colagens que não se referem visivelmente ao arquivo como reminiscência, mas que estão perceptivelmente relacionadas à técnica do desenho de observação. Hockney fala da montagem pensando na técnica, utilizando elementos e recursos do tempo em que a obra foi feita para construí-la, enquanto Jandira utiliza a montagem como processo criativo, resultando em uma característica de sua poética. As obras de Jandira se assemelham às janelas múltiplas, pois também reúnem imagens diversas. Enquanto que em Jandira são imagens diversificadas em tema e cronologia, em Hockney são imagens inseridas por pontos de vistas diversos. Porém, de modo geral, em ambos a montagem é um recurso presente, que caracteriza a obra. São semelhantes quanto à formatividade da imagem como um todo, por fragmentos provenientes de uma colagem (Hockney) ou de tempo diversos (Jandira), que se tornam perceptíveis visualmente aos olhares curiosos que avistam os detalhes que conduzem a esta determinada reflexão quanto à construção compositiva.

Os desenhos de Jandira Lorenz, são como janelas que possibilitam aos olhos ver a imagem como universos interpretativos diversos, de configurações sempre permutáveis. Pelo detalhe, o observador atento pode ter acesso às janelas que afiguram tempos. É o tempo e sua configuração na memória da artista que fará aparecer as janelas e consequentemente, os universos ali possíveis.

O caminho percorrido por Jandira é a chave de acesso aos seus desenhos. Desde criança seu fascínio com as imagens (ilustrações) contidas nos livros de infância e, posteriormente, a docência em artes (história da arte, desenho e gravura), é preponderante no despertar do olhar para a prática do desenho e consecutivamente, para a história. Seu percurso artístico é nutrido por diversas fontes do saber relacionadas diretamente à história da arte, literatura clássica, cinema, teatro, dança e artes visuais. Porém, acentuaremos a influência da mitologia e história da arte na

\footnotetext{
${ }^{3}$ Tradução livre da autora do original: "Para experimentar la metamorfosis constante y el desplazamiento acimutal de las imágenes. Estas, como las mariposas, nos rodean con su danza incessante, con sus movimentos brownianos, con su contagioso pulular".
} 
poética da artista, através de sua obra Sem título, 2012, nanquim sobre papel, 43,6 x $64,5 \mathrm{~cm}$ (Figura 6), como um exemplo.

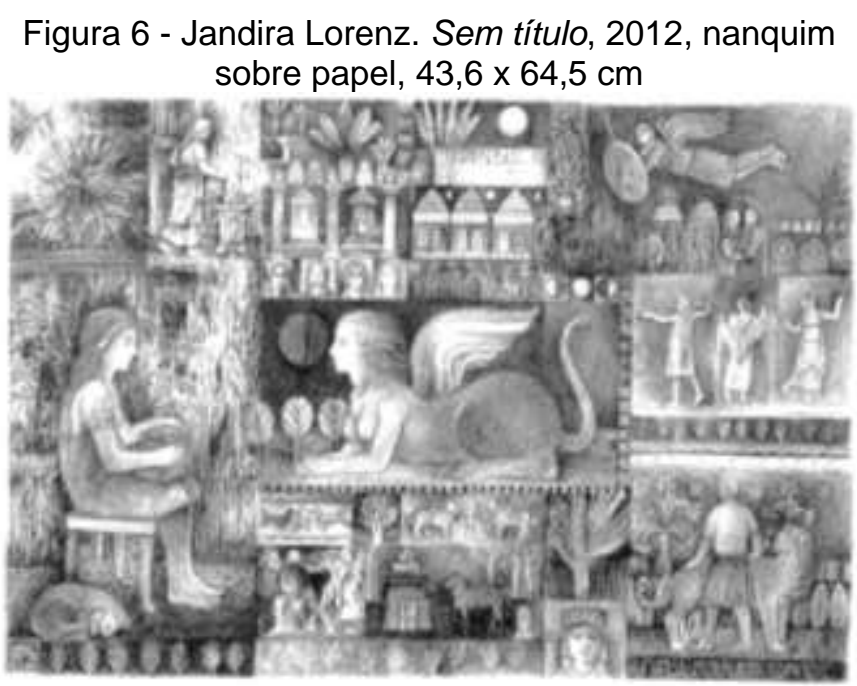

Fonte: Acervo da artista.

Ao observarmos a Figura 6, podemos comparar Jandira a um historiador, que desmonta e monta a história, as descontinuidades, os tempos heterogêneos, que reúnem sobrevivências, anacronismos, sintomas, latências etc. Se a distinção que fazemos do presente e passado é arbitrária, o anacronismo é inevitável, pois como interpretar o passado sem recorrermos ao próprio presente? "O passado conserva-se por si mesmo, automaticamente. Nosso mais longínquo passado adere a nosso presente e constitui, com ele, uma única e mesma mudança ininterrupta" (BERGSON, 2006, p. 175-177).

"Não é evidente que a chave para compreender um objeto do passado se encontra no próprio passado, e mais ainda, no próprio passado que o do objeto?" questiona Didi-Huberman no livro Ante el tiempo. Reconhece, portanto, o anacronismo como uma riqueza, que parece interior aos objetos, às imagens, cuja história tentamos criar (DIDI-HUBERMAN, 2011, p. 36-38) ${ }^{4}$. Com a análise da pintura (afresco) de Fra Angélico do Convento de São Marco em Florença, ele comprova a exuberância, a complexidade e a sobredeterminação das imagens. O estudo do passado é o que abre o olhar para os detalhes até então não vistos e estudados. Mas é também, o presente,

\footnotetext{
${ }^{4}$ Tradução da autora do original: "No es evidente que la clave para comprender un objeto del pasado se encuentra en el pasado mismo, y más aún, en el mismo pasado que el del objeto?"
} 
que ao remeter à uma memória passada (fato passado, acontecimento), abre possibilidades de analogias e entendimento sobre aquilo que a história (cronológica) se mostrou insuficiente. Pensar a história como anacrônica é abrir novas hipóteses para pensarmos as imagens como aquilo que elas carregam, impurezas, complexidades e sobredeterminações.

Os fatos sobrevivem no presente, carregam em si a prova, a latência de uma forma diferente daquilo que foram, designando o trabalho complexo do tempo. A Figura 6 é um exemplo de como isso acontece. Ao focalizarmos o centro dessa imagem há o detalhe que é entendido a partir de sua natureza sintomática, abrindo para significados. E como "o bom Deus habita no detalhe" (DIDI-HUBERMAN, 2013, p.446), é a partir dele, especificamente da frase Et in Arcadia Ego (Figura 7), que se iluminam as possibilidades de ressuscitar fantasmas e iniciar o trabalho analítico.

Figura 7 - Jandira Lorenz. Sem título, 2012, nanquim sobre papel, 43,6 × 64,5 cm (detalhe)

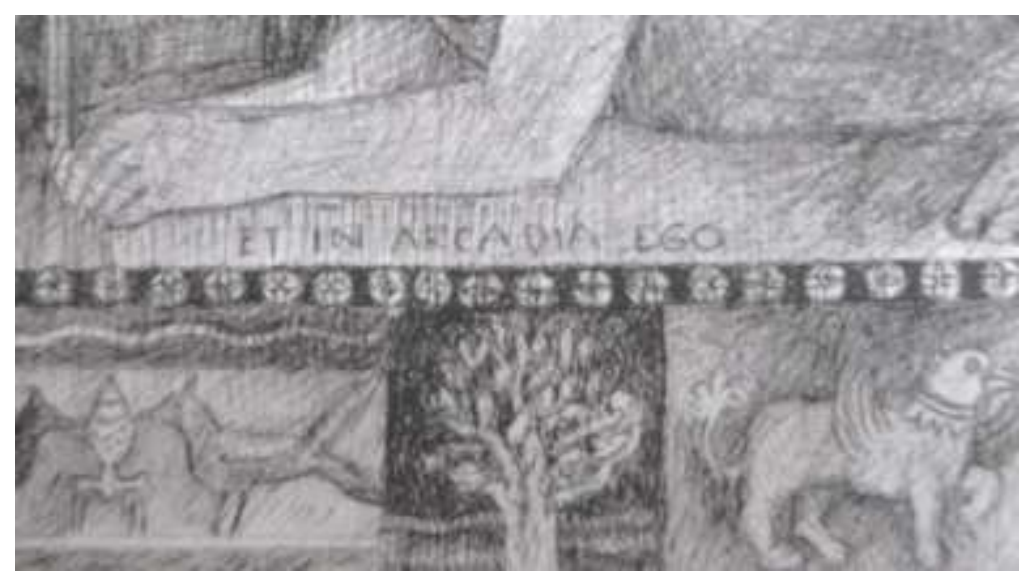

Fonte: Acervo da artista.

O detalhe avistado, e motivo de desdobramentos, é o exemplo de como o olhar, ao ser atraído para a imagem de Jandira, suscita o desenrolar de outras imagens pertencentes a todo universo da linguagem que dialoga entre si, segundo o olho de quem vê. Neste caso, meu olhar atraído pelo detalhe descortinou relações entre a frase e tudo o que ela suscita, quanto ao arquivo imagético de Jandira, seu processo criativo e o ressoar de sua poética, analogamente à teoria warburguiana, como característica interessante e instigante existente em seus desenhos. A obra, sendo um tecido repleto de tramas urdidas pela artista, atrai o leitor e a ele cabe deixar-se 
penetrar e se entregar a este lugar de desejo (de fruição da obra de arte), a essa Arcádia feliz, que é o desenho de Jandira.

A observação do termo Et in Arcadia Ego como detalhe no desenho de Jandira Lorenz proporcionou todas as reflexões sobre memória, tempo, imagem e montagem, conceitos que envolvem teorias para pensar a história das imagens como história de fantasmas, na qual as distâncias temporais, reconhecidas como fragmentos, se combinam como em uma montagem, produzindo uma nova existência.

Seus desenhos representam a ação da memória, onde passado e presente se tecem e se emaranham. É a memória unida ao modo de compor que configura a montagem, por meio de elementos anacrônicos diversos e várias imagens dentro de uma imagem, como diversas janelas de tempo dentro de uma única janela do tempo que presentifica todas as outras imagens. Ou seja, a montagem de Jandira é o resultado do mecanismo da memória, que sob formas de lembranças, via presente, trazem a síntese atual dos fatos passados de modo contingente.

A memória, como a imagem, também joga em todos os quadros de tempo. A imagem pode ser originada por uma pluralidade de fatores heterogêneos, sendo possível receber diferentes interpretações simultaneamente verdadeiras. A memória promove uma impureza essencial, e é na impureza que as coisas sobrevivem. É essa impureza que permite as conexões entre a teoria da montagem e as janelas múltiplas de tempo nas obras de Jandira Lorenz.

A Figura 6 mostra que a montagem é algo intrínseco ao processo criativo de Jandira, ao reunir sob aspecto de colagem, cenas de tempos e histórias diferentes dentro de uma história coabitada por heterogeneidades. Assim são os tempos, uma compilação retrospectiva por imagem de toda a experiência vivida de outros, similar ao procedimento da memória, em transformação perpétua.

O termo Et in Arcadia Ego nos conduz em direção a ideia de um lugar imaginado, espaço que vive a obra de arte e permite ao observador adentrar nesta Arcádia da artista segundo as imagens que nela habitam. Assim, as analogias entre imagens são sempre possíveis e correspondentes às rememorações de Jandira. 
Se observarmos o centro da imagem (Figura 6) veremos uma esfinge e acima dela, outras esfinges adornando colunas dóricas. Apesar da influência iconográfica e funcional egípcia na arte grega, a esfinge que aparece no desenho mais se aproxima da tradição grega pelas pernas de leão, asas de pássaro grande e rosto de mulher. A esfinge do desenho traz características desse passado histórico, similar à imagem da esfinge arcaica (Figura 8) pertencente a 560-550 a.C. e à imagem esculpida no século XX (Figura 9). São imagens que deixam vestígios daquilo que foram. A esfinge de Jandira tem sua particularidade que a difere das outras pelo tempo e contexto, onde pode ser tudo ou algo indiviso de um significado maior, revivendo como ressonância de outras imagens, que lhe emprestam a forma para fazê-la participar deste universo onírico do destempo.

Figura 8 - Esfinge arcaica em mármore, 580-575 a.C. Alt. 72 $\mathrm{cm}$

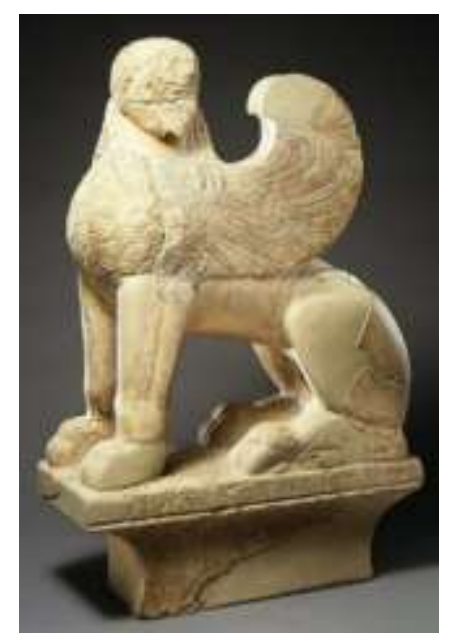

Fonte: Foto da autora. MET Museum.
Figura 9 - Esfinge em bronze. Felipe Moratilla y Parreto, 1982

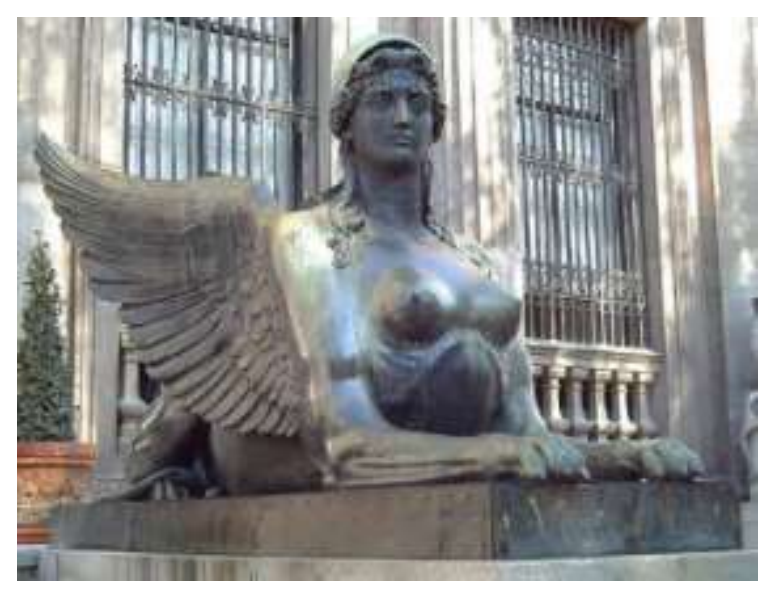

Fonte: Foto da autora. National Archaeological Museum of Spain, Madrid.

A influência da esfinge egípcia na arte grega é evidente. Os gregos guardaram as devidas proporções ao que se refere ao aspecto iconográfico e funcional da esfinge egípcia, guardiã dos túmulos dos Faraós, símbolo solar e essencialmente masculino, nunca possuiu a função de raptor, devorador dos mortos e muito menos o caráter erótico. A esfinge deve ter chegado à Hélade no século XIV-XIII a.C, devido a presença de visitantes, comerciantes e soldados mercenários gregos no Egito. $O$ caráter erótico da Esfinge é um fato grego. Só a partir do século XIII a.C. é que tomou impulso como um ser capaz de marcar presença nos túmulos onde se apresenta como 
protótipo da Quere da morte: guardiã do cadáver e possivelmente sua devoradora. Nesta época, ainda não tinha assumido seu papel de amante demoníaca, de espírito ávido de sangue e de prazer erótico, patenteado na Grécia arcaica com o arrebatamento de mortos e implacável perseguição aos jovens de físico privilegiado (BRANDÃO, 1991, p. 386). Através desses dados sobre a esfinge, percebemos na história das civilizações como as imagens se metamorfoseiam à medida em que são criadas, alterando e adaptando sentidos e significados de acordo com cada cultura.

Figura 10 - Lintel da porta com leão-grifos e vaso com folha de lótus. sécs. II-III a.C. Período

Partiniano

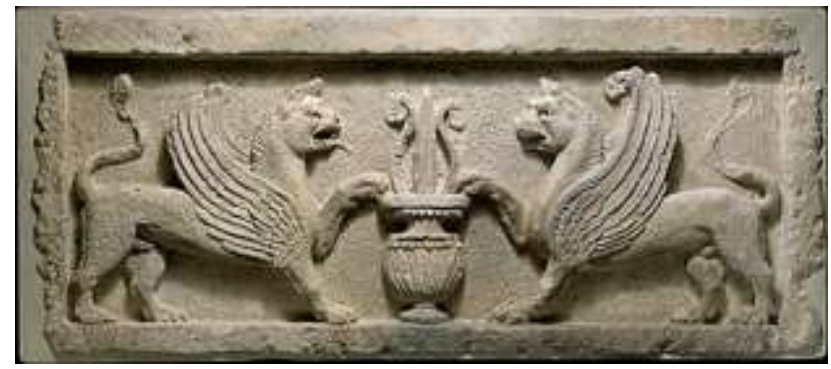

Fonte: Foto da autora. Coleção The Metropolitan Museum of Art.
Figura 11 - Painel com grifo, 1250-1300. Cultura Bizantina. Mármore, 59,7 x 52,1 x $6,5 \mathrm{~cm}$. Possivelmente proveniente da Grécia ou Balcãs

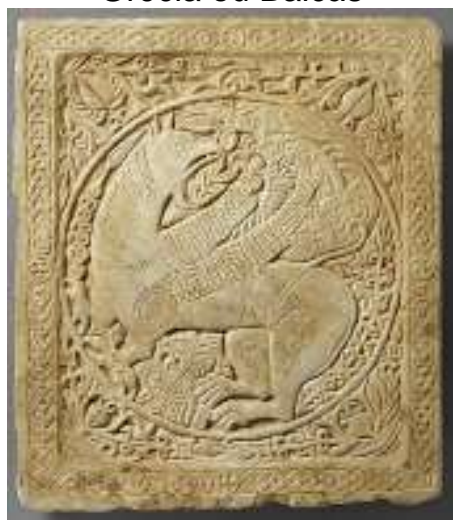

Fonte: Foto da autora. Coleção The Metropolitan Museum of Art.

Abaixo da esfinge do desenho (Figura 6) aparecem grifos, animais com cabeça e asas de águia e corpo de leão pertencentes a diversas mitologias e reproduzido em diversos momentos na História, sendo bastante recorrente na Antiguidade (Figura 10), Idade Média e na época renascentista. A figura do grifo surgiu no Oriente Médio onde babilônios, assírios e persas representaram a criatura em pinturas e esculturas. Sua representação também se tornou comum na cultura grega do século VII a.C. (Figura 11). Para os antigos gregos, os grifos tinham por função guardar os tesouros ocultos do deus Apolo e simbolizavam a força e a vigilância, e também as provas a superar para chegar às riquezas divinas. Estavam também associados a Dionísio, por thes vigiarem a cratera cheia de vinho. No desenho de Jandira (Figura 6) eles aparecem como guardiões, próximos ao templo semelhante a um templo sumério (zigurate) do período Pré-Dinástico (Mesopotâmia), aprox. 3.200 a.C. a 3.000 a.C. (Figura 12) que foram posteriormente copiados pelos egípcios. Alguns simbolismos como este conferem um sentido iniciático e transcendente à obra. 
Figura 12 - Grande Zigurate do Rei Ur-Nammu, Ur, séc. XXI

a.C., Muqayyar, Iraque

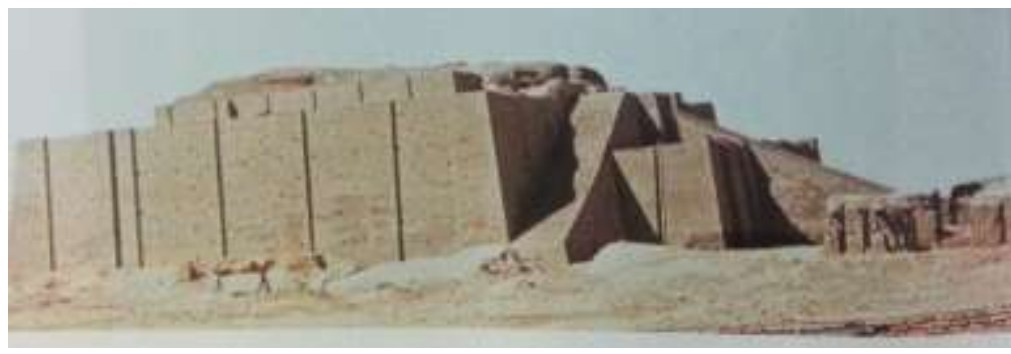

Fonte: DAVIES, 2010, p. 32.

Uma ampla variedade e variações de elementos simbólicos compõem o desenho em nanquim. As formas arquitetônicas, os elementos decorativos, os personagens e suas vestimentas, as figuras míticas, a paisagem, os animais, enfim, todas remetem a diversos tempos e civilizações, diferentes entre si, mas únicos quando no universo criativo da artista. São imagens sobreviventes que agora aparecem metamorfoseadas pelo procedimento poético de Jandira, trazendo novos sentidos e significados, pois carregam um simbolismo herdado, uma memória carregada de energia, que se transformam sempre.

O guerreiro alado (acima no canto direito da Figura 6) tem a ver com as iluminuras cristãs bizantinas e com as transformações iconográficas ao longo do tempo. Como a artista lecionou a disciplina de história da arte, as imagens permaneceram em sua memória e foram reelaboradas pelo tempo. A representação bizantina (Figura 13) é mais esquemática, mas carregada de reminiscências helenísticas, por isso é pertinente também a associação com a figura mitológica do Perseu - guerreiro da mitologia grega que partiu para a missão de decapitar Medusa. Amado pelos deuses, Perseu recebeu para êxito de sua missão a espada e o escudo de Minerva, o capacete da invisibilidade de Plutão e as sandálias com asas de Mercúrio (Figura 14).

Em sua fala, a artista faz uma assertiva sobre as alterações que os tempos colocam e como, de certo modo, esta característica não propositada está inserida em seu desenho, e, principalmente, quanto à figura do guerreiro alado e a relação deste desenho com as iluminuras cristãs bizantinas. 
memória e devem ter sido "retrabalhadas" pelo tempo. É claro que a representação bizantina era mais esquemática, mas a arte de lá vinha carregada de reminiscências helenísticas. (LORENZ, 2013, entrevista pessoal).

Figura 13 - Anônimo. Arcanjo Miguel, 1299. Mosca/Rússia, Galleria Tret'jakov

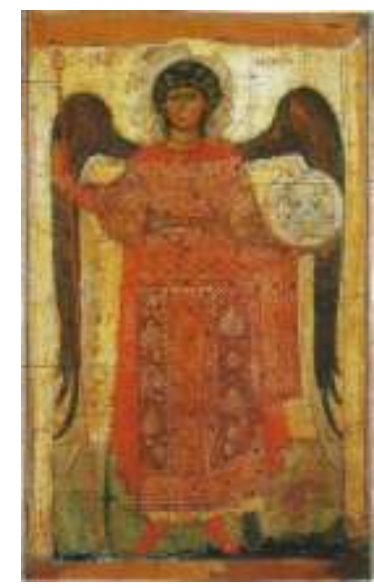

Fonte: ZUFFI, 2007.
Figura 14 - Laurent Honoré Marqueste. Perseu decapitando Medusa, mármore, 1890. Museu de Belas Artes de Lyon

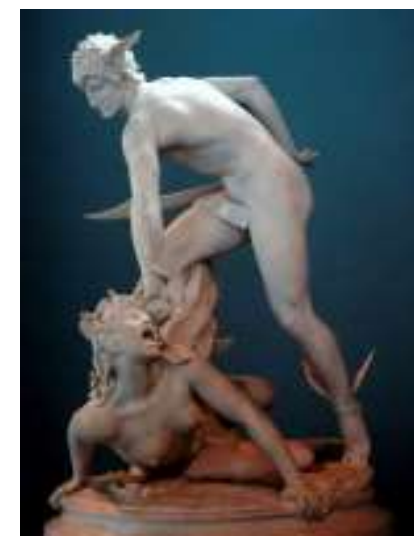

Fonte: Templodeapolo.net, 2014, on-line.

A fala da artista acentua as afirmações sobre o que as imagens no decorrer dos séculos mostram: os tempos reinventando tempos. Também ao lado direito, no centro da Figura 6, há três figuras dançantes, sendo que uma delas tem asas e as outras duas não. Sabe-se que as ninfas (Figura 16) na mitologia grega eram espécies de deusas-espíritos da natureza. Para os gregos, elas habitavam campos, lagos, montanhas e bosques. E muitas ninfas eram a personificação de características e qualidades de deuses gregos. Algumas eram aladas. As Mênades ou Bacantes (Figura 15), também personagens da mitologia grega, eram mulheres seguidoras e adoradoras do culto de Dionísio (ou Baco, na mitologia romana). Durante o culto, dançavam de uma maneira muito livre e lasciva, em total consonância com as forças da natureza.

Figura 15 - Mênade dançando. Período romano. Mármore com $45 \mathrm{~cm}$ de altura. Skulpturensammlung, Dresde
Figura 16 - William-Adolphe Bouguereau. Nymphs and Satyr, 1873. Óleo s/ tela, $260 \mathrm{~cm} \times 180 \mathrm{~cm}$ 


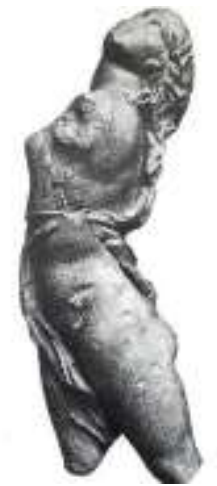

Fonte: STRONG, 1979, p. 61.

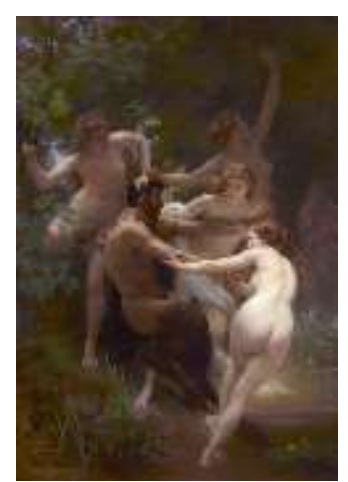

Fonte: Foto da autora. Clark Art Institute.

Se as meninas dançantes de Jandira são Ninfas, Mênades ou uma mistura das duas, não é extremamente relevante. A intenção é indicar como alguns destes poucos exemplos estão disseminados nas imagens de Jandira, fazendo, ao observador, ver características do passado no presente e levantar hipóteses de leitura quando todas essas informações se juntam, pois todo o conhecimento passado é sempre reelaborado na arte do presente. $O$ arquivo mnêmico do artista contém energias latentes, que extravasam no processo de criação e elaboração do trabalho plástico. No caso de Jandira, vê-se um arsenal de referências de conhecimentos adquiridos ao longo do tempo que retornam ao desenho mediante reminiscências de imagens trazidas de filmes, literatura e arte embaralhados ao tempo do agora. O tempo e a memória constroem uma relação analógica com estes trabalhos. Essas imagens fantasmagóricas saltam quando o olho (do observador) é atraído por detalhes, e, é a partir do detalhe que se escava e se descobrem os intrincamentos de campos, de sentidos, de tempos, de modo a evidenciar o poder dos intervalos para estruturar a vida póstuma de um passado que existe de forma diferente (como um eco), que une momentos disjuntos do tempo e faz de um tempo a memória do outro. Continuidade (sobre camadas de descontinuidades) de um vestígio que será sempre vestígio ou fantasma.

A criação, figurativamente dizendo, é a menina sentada pensativa (Figura 17), que segura uma caixa por onde pode libertar mundos, seres e coisas desconhecidas de seu tempo, que se apresentam e sobrevivem neste novo mundo da imagem, abarrotado de tensões, fazendo com que cada leitor aviste os fantasmas, e encontre 
"o bom Deus que habita o detalhe" e mergulhar nessa dialética que propõe a imagem, descortinando significados.

Figura 17 - Jandira Lorenz. Sem título, 2012,
nanquim sobre papel, 43,6 x $64,5 \mathrm{~cm}$ (detalhe)

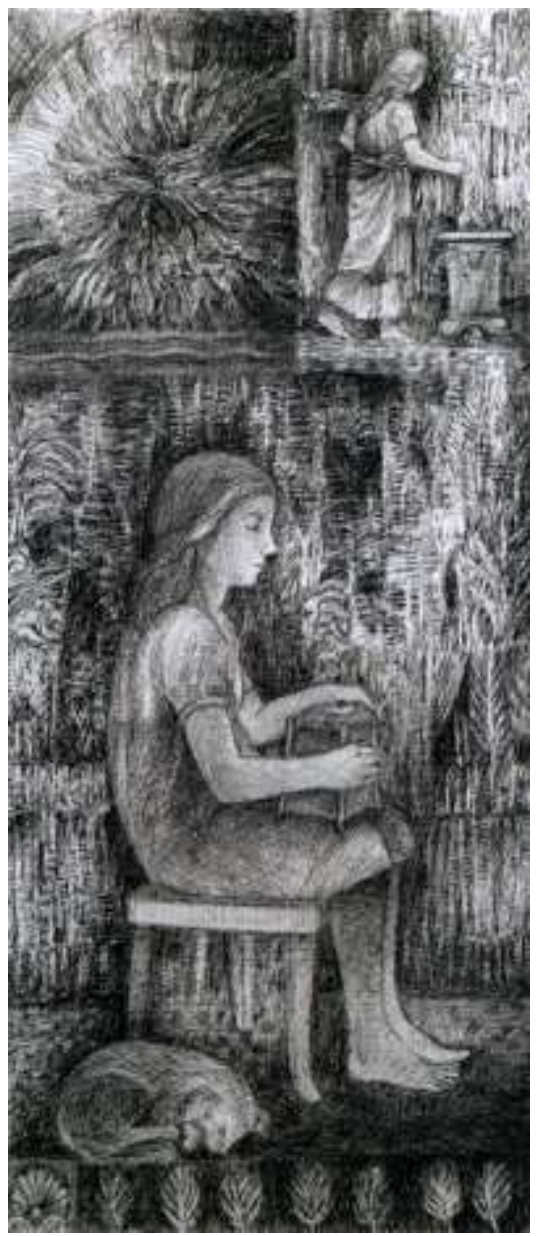

Fonte: Acervo da artista.

No recorte da imagem 6 (Figura 17) as duas figuras femininas usam roupas de épocas distantes. A vestimenta da menina sentada com um vestido simples ou até mesmo uma camisola, em comparação a vestimenta da menina em pé caminhando, semelhante a um traje grego, desperta a percepção para o coabitar de dois tempos tão distantes e tão próximos. "O fato de ser passado, para uma coisa, não significa somente que está distante de nós no tempo. Permanece distante (...), mas seu distanciamento pode dar-se também próximo de nós", afirma Didi-Huberman ao citar 
o que é para Benjamin o fenômeno aurático, comparando-o a um fantasma não libertado (DIDI-HUBERMAN, 2013, p. 161-162).

Jandira imprime sua marca em seus desenhos em janelas múltiplas, revelando as descontinuidades dos processos de memória, atingindo o observador do hoje com um presente que é presente e passado próximo. Tudo nos desenhos de Jandira pode nos remeter a alguma coisa, já que todas as imagens são receptáculos inesgotáveis de lembranças que se tornaram matéria de sobrevivências.

O passado artístico é rico em montagens, basta lembrarmos dos caprichos arquitetônicos (Figura 18) e os outros exemplos também observados nas gravuras e desenhos (Piranese, Goya) feitos durante diversos momentos históricos que logo surgirão em mente imagens do passado que o artista soube transformar em arte, se utilizando do recurso de montagem para dar vazão ao seu arquivo de mundo. O hoje sempre coabitando com o ontem, inventando e reinventando o que está por vir. Não há uma direção correta a seguir, e sim uma constante mutação, apropriação, aglutinação, manipulação, enfim, o que quer que faça com que a arte seja sempre um belo acontecimento, uma descoberta do inapreensível.

Figura 18 - Atribuído a Louis de Caullery. Las Maravillas del Mundo: El Mausoleo de Halicarnaso, El Foro de Alejandria e El Coloso de Rodes, c. 1617. Óleo sobre cobre, 26 x $36 \mathrm{~cm}$

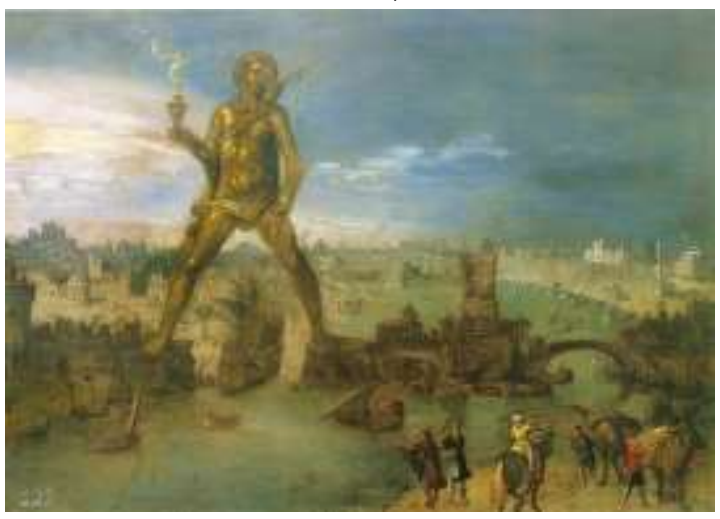

Fonte: ARQUITETURAS PINTADAS, 2011.

\footnotetext{
5 Tradução da autora do original: "El hecho de ser pasado, para una cosa, no significa solamente que está alejada de nosotros en el tiempo. Permanece lejana, es cierto, pero su alejamiento mismo puede darse también cerca nuestro - éste es, según Benjamin, el fenómeno aurático por excelencia -, como un fantasma irredento, como el que retorna."
} 
Ao olharmos a imagem 19 (Figura 19) podemos vê-la como uma montagem, onde a junção de símbolos e figuras representam a narrativa do presente (tempo de sua construção). Por esse ângulo, a montagem novamente se anuncia, pois a própria arte romana inspira-se profundamente nos estilos gregos, como também a arte grega inspirou-se na arte egípcia, revelando no hoje como chegam essas justaposições e colagens que a cultura agregou de modo metamórfico até contemporâneo. Aprendamos com a história e com a arte que mostra através da montagem a possibilidade de que todas as coisas se encontrem (no passado, presente e futuro) e contribuam uma para com as outras, e que cada coisa que vai deixe um pouco de si naquilo que fica.

Figura 19 - Base da coluna de Antonino Pio e de Faustina. Relevo da Apoteose, ca. 161 n.e. mármore. Museu do Vaticano, Roma

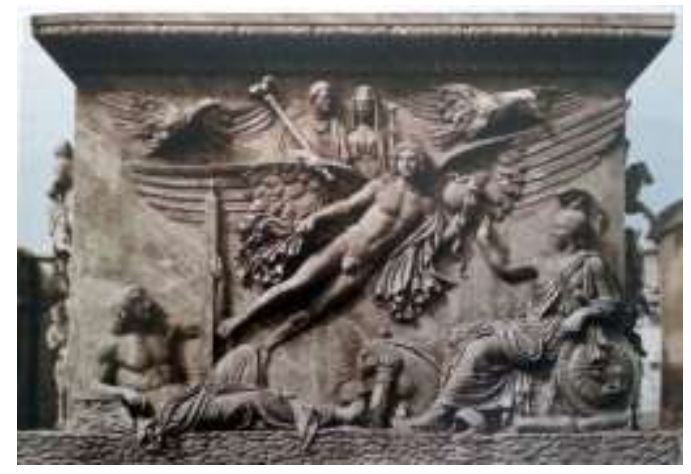

Fonte: DAVIES, 2010, p. 207.

A obra de Jandira Lorenz em suas múltiplas janelas nos abre também todas as portas possíveis constituindo-se em imagens-acontecimento, um conceito chave para Deleuze (2006 e 2007), isto é, imagens nas quais incidem todas as possibilidades e probabilidades, como um hipertexto, em que incidem tempos e obras que não são desta temporalidade. A produção de sentido é o acontecimento. A obra de arte como acontecimento transcende o tempo. A montagem que a artista faz, mediada pela lembrança, responsável pelo movimento de criação, permite a repetição com diferença. Para Gilles Deleuze (2006) a "imagem não é presente", mas um "conjunto de relações de tempos" e que essas relações "estão na imagem desde a sua criação". O objeto da História da Arte não é a unidade do período descrito, mas sua dinâmica, o que supõe movimentos em todos os sentidos, tensões e contradições. A disciplina História da Arte deve ser pensada dentro deste processo em construção e o seu olhar 
sobre as práticas contemporâneas permite ao historiador comparar e refletir sob outras premissas a respeito do tempo e da memória.

No processo criativo da artista, a memória (consciência) percebe essas marcas do passado e interpreta-as à luz do que rememora. O processo de composição artística é uma grande montagem. E pela montagem, o grande arquivo de Jandira resplandece em seus desenhos. Para isso nos servem as imagens, para mostrar que a montagem é algo intrínseco ao processo criativo. E a memória é o motor que alavanca este processo.

Em cada imagem em sua especificidade, há possibilidades de realizar observações e estabelecer critérios, com intuito de traçar abordagens possíveis, tendo em vista a tradição histórica, crítica e estética, de modo a aproximar-se do fenômeno artístico. Não há pretensão de definir o que é irredutível (obra de arte), mas pensar essa impossibilidade de definição por meio de vínculos com outros artistas, com pesquisas, com a história da arte, pensamentos sobre processos criativos e teorias que dialoguem com o objeto de estudo.

Os livros de Didi-Huberman que discorrem sobre imagem e tempo abrem a uma multiplicidade de problemas e debates, inerentes a história da arte e de sua relação e movimentos com modelos de tempo, a noção epistemológica de anacronismo e seus nexos com a sobrevivência, o sintoma e a imagem. Trazem uma contribuição concomitantemente importante para a teoria da imagem, historiografia e filosofia da arte. Didi-Huberman propõe, segundo sua leitura e atualização baseada em Aby Warburg, uma contribuição metodológica com intuito de colocar a questão do anacronismo considerando o paradoxo da imagem, por meio da montagem de tempos heterogêneos. O objeto da História da Arte não é a unidade do período descrito, mas sua dinâmica, o que supõe movimentos em todos os sentidos, tensões e contradições. As obras dos artistas devem ser pensadas dentro deste processo em construção e suas práticas permitem ao espectador, comparar e refletir sob outras premissas a respeito do tempo e da memória. Como potência, a imagem diz, mas a obra não implica apenas o autor, precisa da relação com o espectador, assim como com seus significados. As relações imagem e contexto, imagem e leitura, imagem e mensagem, 
arte, vida, identidade e memória são descritas e desdobradas por Raúl Antelo em Potência da Imagem, que diz:

[...] compreendemos que a história se faz por imagens, mas que essas imagens estão, de fato, carregadas de história. Ela é uma construção discursiva que obedece a duas condições de possibilidade: a repetição e o corte. Enquanto ativação de um procedimento de montagem, toda imagem é um retorno, mas ela já não assinala o retorno do idêntico. Aquilo que retorna na imagem é a possibilidade do passado. Nesse sentido [...], visamos ultrapassar o círculo da subjetividade, potencializando, ao mesmo tempo, a receptividade, que mostra de que modo as formas do passado podem ainda ser novamente equacionadas como "problema". O inacabamento de uns remete-nos às outras, mas a impotência delas carrega-se de renovadas forças de sentido. São essas as "Potências da imagem" (ANTELO, 2004, p. 9-12).

Obras são lidas e imagens são remontadas em um modo de ler seu tempo. É preciso devolver potências à imagem, devolver potência a uma imagem é dar-lhe uma história e uma crítica. Um pouco disso foi o que tentamos fazer aqui, enfocando sobretudo a ligação destes dois artistas com a arte e a ciência, considerando a própria arte como fonte de aprendizagem, em procedimento científico.

O que David Hockney concluiu com sua pesquisa é que os fatos sobrevivem no presente, de uma forma diferente daquilo que foi, porém carregam em si a prova, a latência daquilo que um dia foi, o mesmo que Aby Warburg ao falar da vida das imagens, quis dizer com a sobrevivência póstuma neste texto exemplificada através da poética de Jandira Lorenz.

\section{Referências}

ANTELO, Raul. Potências da imagem. Chapecó: Argos, 2004.

ARQUITETURAS PINTADAS: del Renascimiento al siglo XVIII. Madrid: Fundación Caja Madrid, 2011. [Catálogo da Exposição]

BENJAMIN, Walter. Passagens. Belo Horizonte: Editora da UFMG, 2006.

BERGSON, Henri. O pensamento e o movente. São Paulo: Martins Fontes, 2006.

BRANDÃO, Junito de Souza. Dicionário mítico-etimológico da mitologia grega. v. 1, 3. ed. Petrópolis: Vozes, 1991.

DAVIES, Penélope J. E. et al. A nova história da arte de Janson. Lisboa: Fundação Calouste Gulbenkian, 2010.

DELEUZE, Gilles. Diferença e repetição. 2. ed. Rio de Janeiro: Edições Graal, 2006.

DELEUZE, Gilles. Lógica do sentido. 4. ed. São Paulo: Perspectiva, 2007.

DIDI-HUBERMAN, Georges. Ante el tiempo: historia del arte y anacronismo de las imágenes. Buenos Aires: Adriana Hidalgo, 2011. 
DIDI-HUBERMAN, Georges. La imagen mariposa. Barcelona: Mudito \& Co, 2007.

DIDI-HUBERMAN, Georges. La imagen superviviente: historia del arte y tiempo de los fantasmas según Aby Warburg. Madrid: Abada Editores, 2013.

HOCKNEY, David. O conhecimento secreto: redescobrindo as técnicas perdidas dos grandes mestres. São Paulo: Cosac \& Naify, 2001.

LEAL, Joana Cunha. Entrevista com Hubert Damisch, Revista de História da Arte, Lisboa, n. 3, p. 7-18, 2007. Disponível em: <http://issuu.com/ihafcshunl/docs/rha_3>. Acesso em: junho de 2014.

LORENZ, Jandira. Entrevista. Florianópolis: 16 fev. 2013. Entrevista concedida a Vanessa Bortucan de Oliveira.

TEMPLODEAPOLO. Disponível em: <http://www.templodeapolo.net>. Acesso em: junho de 2014.

ZUFFI, Stefano (Org.). I dizionari dell'arte: Santi. Milano: Mondadori Electa, 2007.

\section{Sandra Makowiecky}

Professora de Estética e História da Arte do Centro de Artes da UDESC - Universidade do Estado de Santa Catarina, Florianópolis, Santa Catarina, Brasil e do Programa de Pós-Graduação em Artes Visuais. Membro da Associação Internacional de Críticos de Arte - Seção Brasil Aica UNESCO. Membro do Comitê Brasileiro de Historia da arte. Associada da ANPAP.

E-mail: sandra.makowiecky@gmail.com

Currículo: http://lattes.cnpq.br/7738155362538526

\section{Vanessa Bortucan de Oliveira}

Possui graduação em Licenciatura em Artes Visuais e Mestrado em Teoria e História da Arte pela Universidade do Estado de Santa Catarina - UDESC.

E-mail: vanessabortucan@gmail.com

Currículo: http://lattes.cnpq.br/0124553547958819 